\title{
A ARTE DA OLARIA NO TURISMO DA REGIÃO ALGARVE, PORTUGAL
}

THE ART OF POTTERY IN THE TOURISM OF THE ALGARVE REGION, PORTUGAL

EL ARTE DE LA ALFARERIA EN EL TURISMO DE LA REGIÓN ALGARVE, PORTUGAL

Jean Carlos Vieira Santos

Prof. do Curso de Geografia da (UEG) Pós-doutorando em Turismo da Faculdade de Economia (FE) da (UALG/PT). jean.vieira@ueg.br

João Albino Silva

Prof. catedrático da Faculdade de Economia (FE) da Universidade do Algarve (UALG/PT). jsilva@ualg.pt

Data de Submissão: 02/03/2015

Data de Aprovação: 26/08/2015

Resumo: Este artigo foi desenvolvido com o objetivo de veicular uma abordagem e analisar um contexto em que a tradicional atividade popular oleira se mantém viva em território luso, preservando uma identidade associada ao turismo e aos seus negócios. Ela se tornou, aliás, potencialmente a ideia central que sustentou a escolha do tema: estudar a realidade contemporânea da olaria de Porches/ Lagoa na região Algarve, sul de Portugal. Desse modo, a proposta deste texto tem, como ponto de partida de análise, um "modelo com os elementos que caracterizam as olarias e os oleiros do Algarve", apresentando uma reflexão com possibilidades multidisciplinares de discussões inexauríveis. A construção deste estudo foi realizada por meio de uma pesquisa bibliográfica, da aplicação de questionário e de trabalhos de campo e gabinete, permitindo uma aproximação dos pesquisadores com a realidade portuguesa investigada. Como resultado, o artigo mostra quem são os oleiros no destino turístico internacional: 50,2\% são de origem algarvia, 33,2\% são oriundos de outros países e 16,6\% são do Alentejo. Tais indivíduos têm entre 50 e 65 anos, e 50,2\% se formaram em escolas.

Palavras-chave: Artista Estrangeiro. Olaria. Algarve. Cultura. Turismo.

Abstract: This article was developed to transmit an approach and analyze a context in which the traditional activity of pottery is kept alive in Portugal, preserving an identity that is associated with tourism and its business. In fact, it potentially became the central idea that supported the choice of theme: to study the contemporary reality of the pottery of Porches/Lagoa in the Algarve 
region of southern Portugal. Thus, the purpose of this text, taking as its starting point a "model of the elements that characterize Algarve's potteries and potters", is to present a reflection on the multidisciplinary possibilities for fruitful discussions. The study was constructed through a literature review, questionnaires, field work, and desk research, enabling the researchers to gain a clearer picture of the Portuguese reality investigated. As a result, the paper shows who the potters are in the international tourist destination: $50.2 \%$ are from Algarve, 33.2\% are from other countries and $16.6 \%$ are from Alentejo. These people are between 50 and 65 years old, and $50.2 \%$ completed high school.

Keywords: Foreign artist. Pottery. Algarve. Culture. Tourism.

Resumen: Este artículo fue desarrollado con el fin de transmitir un enfoque y analizar un contexto en el cual la actividad popular y tradicional de alfarero se mantiene viva en territorio portugués, preservando una identidad asociada con el turismo y los negocios. Esta es, de hecho, potencialmente la idea central que sustentó la elección del tema, que debía estudiar la realidad contemporánea de la cerámica de Porches/Lagoa en Algarve, sur de Portugal. Por lo tanto, el propósito de este texto tiene, como punto de partida del análisis, un "modelo con elementos que caracterizan las alfarerías y los alfareros de Algarve", que presenta una reflexión con posibilidades multidisciplinarias para un debate fructífero. La construcción de este estudio se realizó mediante una revisión de la literatura, aplicación de cuestionarios, trabajo de campo y de gabinete, lo que permitió una aproximación de los investigadores con la realidad portuguesa estudiada. Como resultado, el documento muestra quiénes son los alfareros en el destino turístico internacional: el $50,2 \%$ son de origen de Algarve, el $33,2 \%$ son extranjeros y el 16,6\% son de la región del Alentejo. Estas personas tienen entre 50 y 65 años, y el $50,2 \%$ se formaron en las escuelas.

Palabras clave: Artista extranjero. Alfarería. Algarve. Cultura. Turismo.

\section{INTRODUÇÃO}

ste texto foi desenvolvido com o objetivo de veicular uma
abordagem e analisar um contexto em que a tradicional atividade
popular oleira se mantém viva em território luso, preservando uma identidade associada ao turismo e aos seus negócios. Esta se tornou, aliás, potencialmente a ideia central que sustentou a escolha do tema: estudar a realidade contemporânea da olaria de Porches/Lagoa na região Algarve, sul de Portugal, uma paisagem de confinamento de elementos e investimentos que a define como destino turístico maduro e internacional.

Nesse viés se pretende, ao falar da olaria de Porches/Lagoa/Algarve, confluir a abordagem para a temática "turismo", considerando que ela exercita uma dimensão espacial e territorial com as densidades e as particularidades dos lugares. Quanto à escala de análise deste trabalho, convém destacar 
Ribeiro (1986, p. 57), um especialista dedicado ao estudo geográfico português que, ao caracterizar o sul de Portugal, lembra que "[...] os árabes reforçaram o tom mediterrâneo que os romanos haviam começado [...]". Ao não ignorar o pensamento regional, enfatiza também que os povos do sul historicamente foram mais polidos.

Outra concepção a assinalar diz respeito à demarcação do local, considerando que "[...] aí se encontram mais frequentes vestígios de relações com os navegadores do Mediterrâneo, fenícios, gregos, cartagineses e indígenas de Tartessos. [...] e as principais cidades e estabelecimentos romanos, visigóticos e árabes" (RIBEIRO, 1986, p. 134-135). Sublinha-se que "[...] o Algarve conservou no nome, justaposto a Portugal, a sua poderosa originalidade" (ibidem, p. 166), proporcionando um nexo referencial a essa região; por conseguinte, encontram-se no seu percurso atual uma convergência e a apropriação para (e pelo) turismo. Outro fato narrado pelo autor sobre o Algarve é que:

O geógrafo Estrabão, ao recolher notícias sobre o Promontorium Sacrum (Cabo de São Vicente), começa por notar que ele marca o extremo ocidental não só da Europa, mas de toda a terra habitada. A sua situação e rudeza selvagem impressionaram os antigos, que 0 povoaram de lenda. (RIBEIRO, 1986, p. 105).

O encadeamento deste artigo possui como escala de análise o município de Lagoa (Figura 1) que, por sua vez, pertence ao Distrito de Faro, com área de $88,25 \mathrm{~km}^{2}$, tem limites geográficos com Silves, Portimão e Oceano Atlântico, e está subdividido em quatro freguesias. Nessa escala de trabalho, elegeu-se para uma apreciação a freguesia de Porches, principal centro oleiro regional, colocando também esse território como ponto de partida para compreender a atual dimensão econômica, social e cultural das olarias no Algarve. Vale mensurar que o recorte de investigação está:

[...] situado atualmente junto s E. N. 125, a 5 km de Lagoa (sede do Concelho), é uma pequena aldeia empoleirada no alto de um pequeno outeiro. O povoado (pois antes existiu a Porches Velho, destruída pelo terremoto de 1755) surgiu à volta da Igreja Matriz, construída no século XVI, contudo foi quase completamente destruído pelo terremoto de 1755. Só em 1834, a Freguesia de Porches, até então pertencente ao concelho de Silves, passou ao concelho de Lagoa, o qual havia sido criado em 1773. (OLIVEIRA, 1987, p. 88). 
A Estrada Nacional 125, principal meio de acesso a Porches, é a mais antiga via longitudinal do Algarve. As principais olarias da região estão localizadas às margens dessa rodovia, caminho de mobilidade de turistas e moradores. Ao conjugar uma perspectiva espacial contemporânea que acumula a arte tradicional oleira algarvia a outras partes do mundo, a estrada molda valores e costumes do ponto de vista do desenvolvimento da atividade turística, sendo essa arte popular utilizada como elemento essencial nos comércios espalhados ao longo da rodovia.

É necessário ressaltar uma breve referência: margeando essa via longitudinal estão as particularidades culturais expressas no saber fazer e no comércio oleiro regional. Há paisagens humanizadas pelos sujeitos sensibilizados com a arte popular da olaria, os quais agrupam diferentes saberes e fazeres turísticos a partir de seus atrativos, conteúdos e especificidades.

Figura 1: Região Algarve

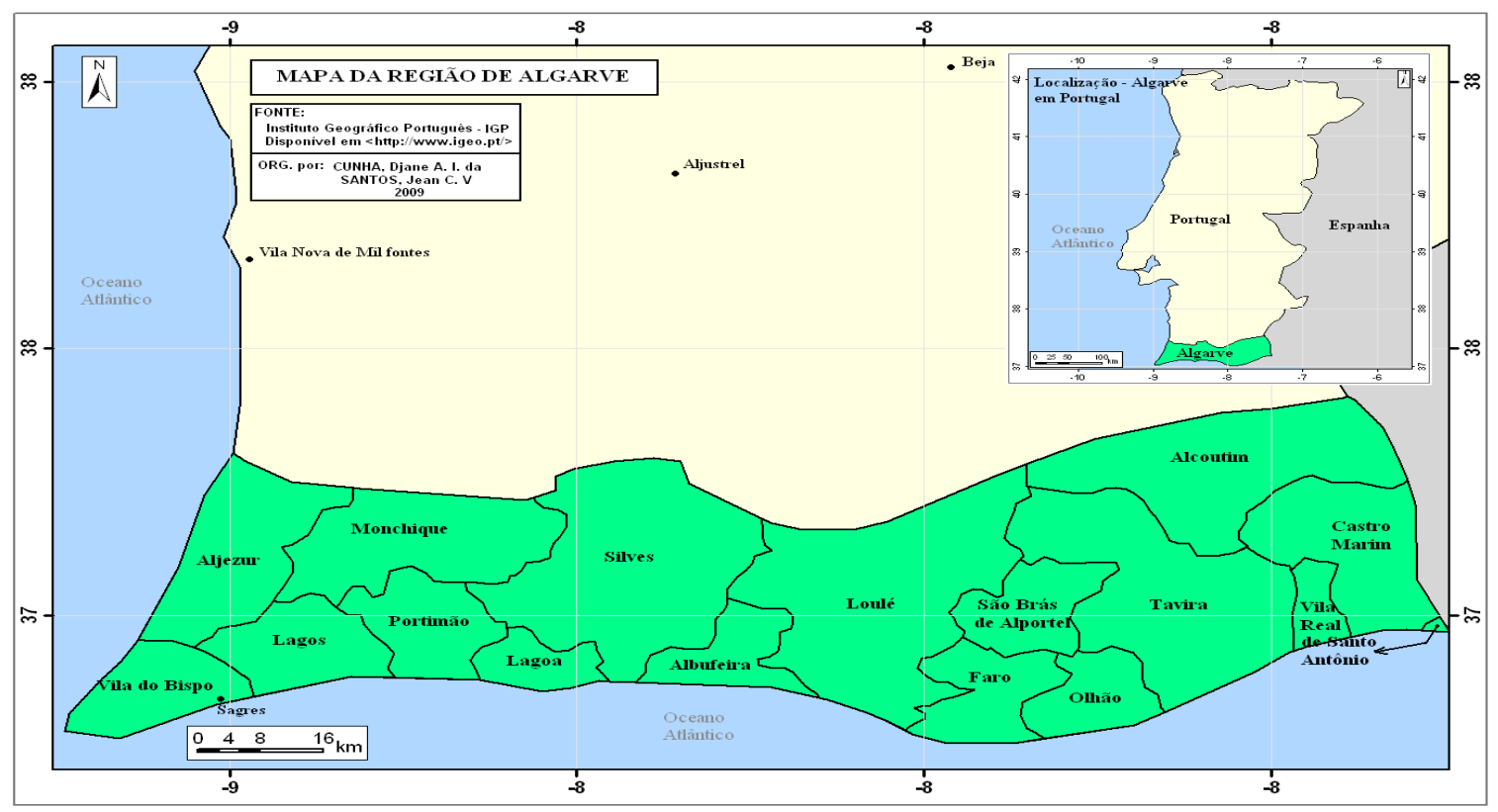

Fonte: Santos (2009).

Emergem-se assim os lugares das olarias e dos sujeitos oleiros, desempenhandoum papel fundamental na eficácia simbólica destes coma cultura regional. Nesse entremeio, o presente artigo buscou conhecer, dimensionar e analisar o atual contexto da arte popular oleira, porque cientificamente pouco se disse sobre essa tradição na região Algarve. 


\section{OLARIAS E OLEIROS: UMA ABORDAGEM TEÓRICA NO CONTEXTO DA ATIVIDADE TURÍSTICA}

A olaria é um espaço onde o oleiro preserva a sua identidade histórica e patrimonial, proporcionando o surgimento de obras que são chamadas de artesanato que, no caso da região Algarve, são produtos de excelência que complementam e contribuem com o desenvolvimento da atividade turística, fortalecendo o destino internacional.Com oturismo, os produtos comercializados nas olarias algarvias alcançam outras fronteiras e, hoje, pode-se afirmar que essa arte é um símbolo vivo da história contemporânea regional.

Nesse contexto, Pla (2006, p. 5) arrazoa que "[...] de todas las formas que la ansiedad del ser humano frente la existencia y la necesidad pueda adoptar, creemos que la que lleva a la expresión del impacto del barro obedeciendo al dictado de sus dedos, es hallazgo más antiguo". Não à toa, Conde (2013, p. 127) define a olaria como "[...] as logeas dos oleiros. O lugar onde se faz a louça, derivando do latim Tiglina. Surge também o termo Ollaria como derivado do latim olla, panela".

Assim, a compreensão de olaria parte de uma definição cuidadosa de arte popular que, para Freitas (1978, p. 3-4):

As formas tradicionais do artesanato ligam-se estreitamente às comunidades rurais, ao seu modo de vida e habitat, à economia familiar, às tradições religiosas e culturais; são formas transmitidas de geração em geração, que variam pouco ao longo do tempo. Este cunho conservador da arte popular constitui um elemento importante da sua definição.

As unidades de produção oleiras detêm processos de organização inspirados parcialmente em antigas formas de organização do trabalho, baseados "[...] numa relativa autonomia, na experiência e no saber fazer dos Mestres oleiros e também, mais recentemente, das pinturas" (CONDE, 2013, p. 98).

Diante disso, as olarias são conceituadas "[...] como uma indústria antiga, apresentando transformações profundas que imprimiram à paisagem traços marcantes, que atestam sua importância, podendo-se verificar os processos evolutivos pelos quais teriam elas passado" (CAMPOS, 1955, p.125). Vale 662 
ilustrar que os territórios oleiros também são definidos como "[...] alfarería. Arte o industria de fabricar o decorar objetos de barro endurecidos mediante cocimiento. Lugar donde se fabrica cerámica. Término genérico para los objetos de barro" (RAVINES; VILLIGER, 1989, p. 210); eles "[...] são locais em que a vida social e o ritmo de vida definido pela produção artesanal vai se especializando" (SANTOS; SANTOS, 2011, p. 6).

O ofício (e a tradição) oleiro proporciona identidade e valores socioculturais únicos; é, pois, o "oficial que faz a louça, obra de barro" (CONDE, 2013, p. 127). Outra figura incontornável para o artista oleiro são as pintoras, aquelas que dão "[...] cor e vida ao riscado, feito previamente pelo artesão nas suas peças" (CALADO, 2013, p. 83).

Com base na obra de Calado (2013), pode-se referir ao oleiro como um artista que molda as suas peças com vistas a invulgar beleza e simplicidade, usando instrumentos suficientemente perfeitos para o ajudarem a explanar sua arte. A olaria é também sua oficina, onde se torneia o barro, transmitem-se conhecimentos e perpetua-se o saber. Desse modo, a atividade oleira é parte de uma cultura única, que se desenrola na riqueza de uma atividade gestual, criativa e decorativa, reflexo de saberes e experiências de vida.

Nesse contexto, Santos (2011), por exemplo, chama a atenção para a realidade da olaria de Porches/Algarve a partir da década de 1960, que, à mercê de algumas circunstâncias favoráveis:

[...] dentre elas o turismo, foi possível, num impulso feliz, recuperar algo desse passado artístico manufatureiro, nomeadamente o artesanato, trazendo novamente ao conhecimento das pessoas o valor artístico, qualidade e utilidade de verdadeiras obras de arte que, tendo preenchido o cotidiano do passado, se quedavam no esquecimento. (SANTOS, 2011, p. 474).

A posição acabada de descrever se referirá, porventura, à obra de Oliveira (1987), preconizando a noção de uma cultura popular associada ao turismo, em que se privilegia seguinte análise: "[...] a partir da década de 1960 do século XX, a olaria em Porches recebeu novo impulso, surgindo barros artísticos que cruzam a técnica regional com a inspiração própria e original" (OLIVEIRA, 1987, p. 88). 
De fato, as olarias do destino turístico Algarve tornaram-se espaços de atração, visitadas anualmente por milhares de turistas nacionais e estrangeiros. De acordo com Freitas (1978, p. 6), as peças algarvias fazem "[...] grande sucesso. No estrangeiro a cerâmica de Porches tem sido objeto de comentários favoráveis em numerosas revistas e jornais".

O êxito alcançado conduziu os sujeitos proprietários de antigas olarias à procura de instalações mais amplas e modernas - hoje são comércios cuja sobrevivência está ligada diretamente ao desenvolvimento da atividade turística. Por meio do turismo, essa arte estabelece inter-relações e interdependências profundas com todos os setores econômicos existentes no sul de Portugal, fazendo parte da nova dinâmica desse destino turístico internacional.

\section{INTERNACIONALIZAÇÃO E MODERNIDADE DA OLARIA DA} REGIÃO ALGARVE

Aportandonavertenteinternacional da regiãoAlgarve, parte-sedopressuposto que a olaria popular também se internacionaliza no mesmo período de tempo, embora pontualmente nesse tempo e espaço seja possível verificar algumas particularidades e densidades que aproximam os acontecimentos - isso será explicitado no próximo tópico, na Figura 4, que apresenta o eixo metodológico norteador desta investigação. Pode-se afirmar que a internacionalização dessa região no sul de Portugal geralmente é tomada como resultado de um processo de turistificação complexo em que participam o Estado e a iniciativa privada.

Ao regressar à primeira metade do século $\mathrm{XX}$, pode-se afirmar que, durante todo esse período, "[...] as praias do Algarve mantiveram-se essencialmente como pequenas estâncias frequentadas pela população da província e do Alentejo" (CUNHA, 2012, p. 127), sendo praticamente desconhecidas dos estrangeiros e dos próprios cidadãos do país, e suas possibilidades de atração eram bastante reduzidas. Até o início da década de 1960, o Algarve tinha forte índice migratório, seja no distrito de Faro ou no resto do país, porém já se caracterizava na região um pré-turismo. Segundo Cunha (2012, p. 126), tal localidade era encarada como estância de inverno: "[...] com base, principalmente, na Praia da Rocha, o turismo algarvio deu poucos sinais de desenvolvimento até o início da década de 1960 e pouca atenção mereceu por parte dos poderes públicos". 
As ligações de trens entre Lisboa e Faro eram desconfortáveis, com aproximadamente sete horas de viagem, em média; e as estações que serviam às localidades turísticas não tinham luz elétrica. Pela sua modernidade e dimensão, o primeiro hotel - Vasco da Gama, em Monte Gordo -, só foi aberto em 1960 e, nos primeiros anos daquela década, o turismo algarvio tinha características de passagem, apoiado em menos de meia dúzia de unidades hoteleiras. Porém, a partir de 1960, as acomodações de estrangeiros cresceram mais rapidamente do que no resto do país, multiplicando-se por quatro até 1963 , ao passo que, no resto de Portugal, aumentaram de 1,5 de vezes (CUNHA, 2012).

Em geral, outro ponto a ser destacado no texto de Cunha (2012) concerne aos sinais encorajadores que, associados à evolução ocorrida no sul da Espanha, levaram o secretário nacional da Informação a preparar, em 1963, um Plano de Valorização Turística do Algarve. Nesse plano foi elaborado um esboço de zoneamento turístico, a fim de se criar uma adequada cobertura regional de equipamentos turísticos.

Nessa trajetória de consolidação do turismo internacional no Algarve, Cunha (2006) chama a atenção para o ano de 1964, considerando-o um período em que ocorreu a explosão do turismo lusitano e que marca o verdadeiro início de desenvolvimento do setor no país. Procurava-se adaptar a organização administrativa às novas situações, pela transformação da Direção de Serviços de Turismo em Comissariado do Turismo, que, pouco tempo depois, deu lugar à Direção-Geral do Turismo e ao Centro de Formação Turística e Hoteleira, destinado a coordenar a formação profissional e a criação da Secretaria de Estado da Informação e Turismo.

No mesmo período, o autor reflete ainda que os grandes empreendimentos turísticos se desenvolveram:

[...] em novos centros, com destaque para o Algarve, a Madeira e Troia que polarizaram as atenções e concentraram os investimentos levando à perda de posição dos centros tradicionais. Constroem-se os aeroportos de Funchal e do Algarve permitindo estabelecer relações aéreas para os principais centros emissores. (CUNHA, 2006, p. 86).

Essas mudanças apontadas pelo autor conduzem a dizer que tal fase 
altera os padrões de comportamento dos visitantes e dos moradores nessas regiões, potenciando novas formas de vida nos lugares, além de estabelecer uma ruptura com o passado. As mutações serão consonantes com os padrões de internacionalização que chegam às regiões de Portugal, especialmente ao Algarve.

Aliás, por considerar essa linha de tempo, as questões da internacionalização do território algarvio tornaram-se mais intensas a partir da metade da década de 1960, com a construção do Aeroporto Internacional de Faro (1965) e o surgimento dos hotéis de luxo de quatro e cinco estrelas (Penina, Balaia, D. Filipa, Alvor Praia e Algarve). Nessa perspectiva, o turismo no Algarve evidencia mudanças estruturais:

Têm lugar os primeiros investimentos estrangeiros no Algarve (quase
todos provenientes da Inglaterra e da Holanda); evidenciam-se os
investimentos em: restaurantes, pequenas companhias imobiliárias,
surgindo mais tarde as multinacionais; fortes taxas de crescimento dos
turistas e das dormidas; desenvolvimento de atrações turísticas não
naturais: Marina de Vilamoura, Aldeia das Açoteias, Campos de Golfe.
[...] O turismo assume-se como atividade principal. (GONÇALVES,
2003, p. 262).

Nesse horizonte temporal, Cunha (2003, p. 101-102) afirma que, de praticamente desconhecido no início da década de 1960 - pois ocupava lugar secundário no turismo nacional -, o Algarve passou a se identificar com o turismo português e a constituir a sua marca: "o turismo português passou ser o Algarve e o Algarve passou a ser sinônimo de turismo". Após um longo período de crescimento, o local ocupou o primeiro lugar do turismo português, o que lhe permitiu se transformar num dos destinos mais importantes do mundo.

No período de duas décadas passadas e no início dos anos de 1990, a dimensão e a expressão do turismo algarvio quase duplicaram, tanto na oferta como na procura, o que traduziu um crescimento superior à média mundial. Essa região tornou-se potencialmente não só um destino de turismo internacional uma vez que se passou a dar especial atenção ao binômio sol e praia -, como também um local de residência de estrangeiros oriundos principalmente de países do norte da Europa. 
As referências e as abordagens teóricas apresentadas apontam para uma forte conexão entre os lugares que formam a região Algarve e a realidade do turismo internacional. Assim, parece importante que tal argumento de análise teve forte influência na olaria algarvia, pois é possível reconhecer que ela também se internacionalizou ao longo do tempo - esse fato é simbolizado pelos elementos constantes na Figura 4, que mostram os atores por meio de uma compreensão sistêmica de sua realidade.

Santos (2011), por exemplo, chama a atenção para a realidade da olaria de Porches/Algarve a partir da década de 1960, que, à mercê de algumas circunstâncias favoráveis:

[...] dentre elas o turismo, foi possível, num impulso feliz, recuperar algo desse passado artístico manufatureiro, nomeadamente o artesanato, trazendo novamente ao conhecimento das pessoas o valor artístico, qualidade e utilidade de verdadeiras obras de arte que, tendo preenchido o cotidiano do passado, se quedavam no esquecimento. (SANTOS, 2011, p. 474).

A posição descrita se refere à obra de Oliveira (1987), preconizando uma noção de cultura popular associada ao turismo. Privilegia-se a análise de que, "[...] a partir da década de 1960 do século XX, a olaria em Porches recebeu novo impulso, surgindo barros artísticos que cruzam a técnica regional com a inspiração própria e original" (OLIVEIRA, 1987, p. 88).

Conforme os contributos teóricos ressaltados nesta pesquisa, é possível afirmar que a olaria de Porches/Algarve acompanhará espontaneamente as mudanças regionais, sobretudo com a construção do Aeroporto Internacional de Faro (1965) e com as transformações políticas e econômicas no turismo de Portugal e Algarve apontadas por Cunha (2006). É, porquanto, uma ruptura temporal que privilegia a análise em função de uma região que atualmente se constitui destino internacional.

É nesse enquadramento que estão as mutações ocorridas nas últimas décadas do século XX e no início do século XXI. Inserido na mesma linha de tempo a que, em geral, tem-se feito referência, no início da década de 1960 chega ao Algarve o irlandês Patrick Swift, que vivia com a família em Londres. Segundo 
uma das filhas, que atualmente é gestora da Olaria Algarve, o pai soube da região pelo irmão, que viajava pelo sul da Europa (Itália, França, Espanha e Portugal) interessado em conhecer a produção de vinho nesses territórios, e não a olaria.

Soube-se, durante os trabalhos de campo, um pouco da história que levou Patrick Swift ao Algarve, primeiramente a Carvoeiro. Segundo sua filha, o pai estava à procura de um lugar com mais luz que Londres para pintar; então, foi informado que:

Um sítio que ainda não é conhecido, um cantinho lindo, lindo, lindo escondido é o Algarve. E pronto, vieram cá passar seis meses. Encantou-se com o que encontrou cá e voltou para Londres, vendeu o que tinha por lá e decidiu mudar para o Algarve. Quando veio pra [sic] cá, tinha duas filhas pequenas e uma esposa, e precisava de uma maneira de gerir algum para a família. E veio logo para Carvoeiro. E depois conheceu o Lima de Freitas, que tinha casa em Carvoeiro. Tinham os dois a mesma ideia de tentar salvar a indústria aqui em Lagoa. (ENTREVISTA INFORMAL, ago. 2014).

Santos e Lourenço (2012) também preconizam esse início durante a década de 1960. De acordo com os autores, quando o artista irlandês Patrick Swift chegou pela primeira vez ao Algarve, percebeu que as olarias, outrora numerosas:

[...] tinham entrado numa rápida decadência, prevendo-se o fim desta indústria e com ela a natural extinção das técnicas populares que retinham todas as qualidades da louça fabricada num passado tão longínquo. Por essa altura, Lagoa contava com apenas três oleiros em atividade, quando poucos anos antes ainda existiam várias olarias na vila. O último oleiro profissional de Lagoa chamavase Gregório Rodrigues, pai do Mestre Fernando Rodrigues, de Lagoa, que trabalhou na Olaria Carlota até meados dos anos 1970. (SANTOS; LOURENÇO, 2012, p. 22).

Assim que conheceu as peças de barro não decoradas em pequenas olarias e feiras locais, Swift percebeu a necessidade e a sensibilização de elaborar um novo negócio, mas com peças decorativas, com vistas a revitalizar a tradição. Ao se conscientizar sobre a potencialidade oleira regional, o artista associou-se ao pintor, desenhista e escritor português Lima de Freitas e, por volta de 1968, eles criam o Centro de Artes e Ofício chamado de olaria do Algarve, no qual 
um grupo de habitantes de Porches aprendia as técnicas de modelar o barro; e outro, as de pintura de peças. Com base nesses apontamentos, não se pode deixar de reconhecer as palavras de Lima de Freitas:

Em 1968 eu próprio e o meu amigo irlandês, o pintor Patrick Swift, resolvemos criar em Porches, povoação algarvia perto de Lagoa, um pequeno estúdio artesanal de cerâmica, movidos sobretudo pelo desejo de tentar salvar uma tradição local em vias de desaparecer. [...] Assim o estúdio de Porches, a que demos o nome de Olaria Algarve, se tornou conhecido por uma cerâmica que respeita o cunho tradicional da olaria rústica algarvia, ao mesmo tempo em que desenvolve os valores artísticos da temática decorativa. (FREITAS, 1978, p. 5).

A partir da parceria entre Patrick Swift e Lima de Freitas, percebe-se que eles, em seus propósitos, preconizavam que era preciso defender essa arte popular. Desse modo, eles foram responsáveis por inserir a pintura nos objetos de barro, dando formação às pessoas do lugar e recriando cores e desenhos, como artistas que eram, sem deixar de manter o que já existia no local. Segundo a filha de Patrick Swift, "[...] as pinturas escolheram padrões tirados do antigo, mas modificados para poderem ser pintados facilmente cá pelas senhoras. $O$ antigo é a ideia das folhas com pezinho, isto é tudo algarvio" (ENTREVISTA INFORMAL, ago. 2014).

Nesse contexto, quando reconhecem que a olaria do Algarve se aproxima do fenômeno turístico, Santos e Lourenço (2012, p. 25-26) enfatizam que "[...] as peças foram valorizadas por portugueses de norte a sul do País, e estrangeiros que vinham passar férias na região". Ao trazer de volta a arte popular oleira para o centro das atenções de moradores e turistas, Patrick Swift tornou-se uma referência no sul de Portugal, mesmo provocando mudanças nas práticas sociais, culturais e econômicas da atividade artesanal. Com a introdução da lógica capitalista associada ao turismo, a Olaria Algarve (Figura 2) traduz valores, atitudes e comportamentos de uma região que se tornou internacional.

Há o convívio com a modernidade, as influências que vêm do mercado e do espaço e, sem dúvida, com mutações e uma série de novos hábitos e costumes que chegam ao destino, associados à presença de turistas e moradores estrangeiros. Trata-se, por um lado, de uma realidade comercial atual que, 
inserida num modo de vida contemporâneo, estabelece outras relações, como a criação do Café Bar Baco junto à olaria do Algarve (Figura 3), uma tradição do norte da Europa que se estabelece na vida do lugar, no lazer e na capacidade de coexistência entre o pub e a arte oleira, entre o espaço global e o local.

A ideia era ter um espaço para as funcionárias tomar um cafezinho, e a outra é quando as pessoas vêm cá para fazer compras, poder sentar, relaxar, apreciar. Não sentir que eles vão entrar e sair, é um espaço bem definido. (ENTREVISTA INFORMAL, ago. 2014).

Figura 2: Parte interna (comercial) da Olaria Algarve em Porches

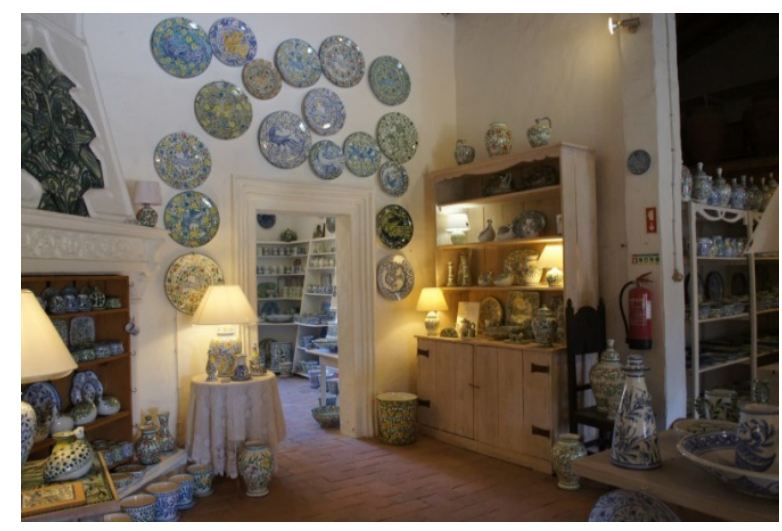

Fonte: VIEIRA SANTOS, J. C. (2014).

Figura 3: Arte e pintura no Café-Bar Baco, junto à olaria do Algarve

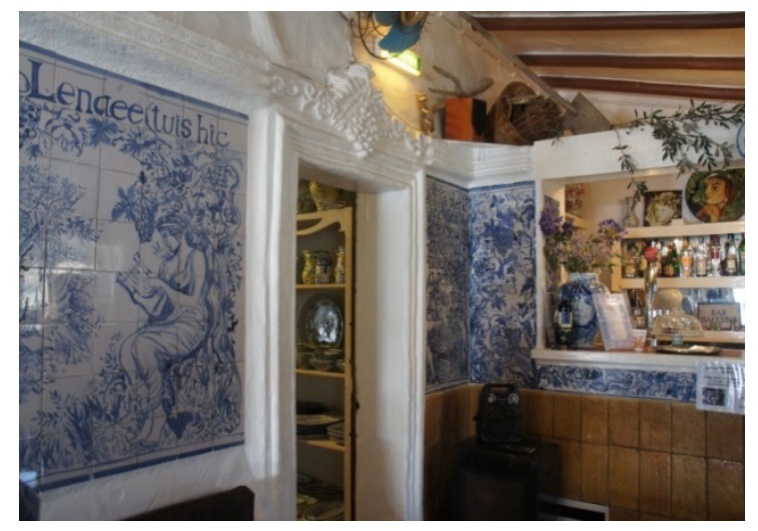

Fonte: VIEIRA SANTOS, J. C. (2014).

Há de se referir, ainda, a outros importantes fatos ocorridos especificamente nas décadas de 1970 e 1980, em que se continua a constatar a internacionalização da olaria algarvia. À época, chegaram à região o ceramista moçambicano Jorge Mealha e os escoceses Janet e Ian Fitzpatrick, esse último formado no curso de Belas Artes da Universidade de Edimburgo. Eles trabalharam juntos por aproximadamente uma década na região Porches e: 
Em 1982, o ceramista Jorge Mealha abriu um novo atelier em Lagos e Ian Fitzpatrick tornou-se proprietário da Olaria Pequena, apresentando agora um estilo de artesanato ligado à azulejaria tradicional portuguesa pela sua técnica, mas de inspiração mais contemporânea, de novas peças com motivos típicos locais. (SANTOS; LOURENÇO, 2012, p. 30).

Os dois casos apresentados têm se distinguido da maior parte das outras casas de artesanato na paisagem de Algarve, especificamente por possuir produção própria. Se já são raras as fábricas de peças, há a ressignificação da pintura. Na carência de tempo disponibilizado à produção, os oleiros estrangeiros dão lugar às práticas da arte decorativa relacionadas à azulejaria e às cerâmicas que chegam de outras regiões do país; nesse caso, os artesãos contemporâneos sedimentam suas técnicas, tradições e cultura.

Assim, já não causam surpresa as palavras de Freire (2013, p. 1), que assevera que "[...] a arte tradicional portuguesa está a ser renovada por mãos estrangeiras". Nesse sentido, Claval (2006, p. 106) interpreta que os homens não param de imaginar "[...] novos valores, de construir novas classificações e de traçar novas fronteiras". Relacionada à nova fronteira, uma particularidade interessante a ser sublinhada é novamente o caso do irlandês Patrick Swift, responsável pelas profundas transformações que ocorreram na Olaria de Porches/Lagoa/Algarve, associando essa nova dinâmica ao turismo regional.

Desse modo, é possível sistematizar alguns tópicos que estão associados a esse estrangeiro que foi aceito pela comunidade local. De fato, ele adere às mesmas preocupações dos portugueses de manter a tradição e o ofício oleiro popular, tendo inicialmente buscado valores que associavam as pinturas das cerâmicas à arte portuguesa, além de associar a existência destas aos objetivos dos moradores, proporcionando uma comunicação entre nativo e estrangeiro, entre o de dentro e o de fora:

Em Assembleia de Freguesia do ano 2011, ficou deliberado dar o nome do artista a uma das ruas principais de Porches (da igreja ao depósito de água), uma vez que, além de transportar o nome da vila para as mais variadas partes do mundo, foi grande benemérito. Da sua grande obra registram-se: projeto de restauro do Restaurante o Leão de Porches, a entrada da Escola Internacional do Algarve, Painel na parede dos quartos de banho públicos, projetou o prédio que 
abriga a Olaria com vários painéis de sua autoria, Quadros da Via Sacra na Igreja de Porches. A Junta de Freguesia tem outras obras doadas acondicionadas em armazém. (SANTOS; LOURENÇO, 2012, p. 27-28).

Acerca da realidade encontrada em Porches, pode-se dizer que, parafraseando Claval (2006), ao se congregar em torno de preceitos comuns, os grupos abolem as distâncias psicológicas que existem entre os membros, o que lhes permite triunfar sobre a dispersão associada frequentemente às necessidades da vida. 0 componente de aceitar o de fora, quando atinge o alcance espacial de base local, revela a escala pessoal do sujeito aceito e a maneira como ele vive, deixando de instaurar desconfianças e ameaças por parte daqueles que são do lugar.

Diante da realidade supracitada, observa-se que os novos oleiros estrangeiros que chegam ao destino turístico internacional Algarve vêm com outras modalidades de formação. Os novos saberes, talvez não na sua totalidade, rompem com os modos de vida comercial tradicional e com aqueles que se encontram isolados das influências do mercado e das velocidades do mundo moderno, apresentando suas particularidades e densidades que possuem um movimento direcionado para o fenômeno turismo.

Consequentemente, as olarias do município de Lagoa deixaram os territórios centrais dos núcleos urbanos e sedimentaram seus comércios às margens da Estrada Nacional 125. Demonstra-se, pois, que tais grupos reconhecem a importância desse fluxo de pessoas para comercializarem seus produtos. No sul de Portugal existem duas linhas: uma de grupos oleiros de base local e outra, estrangeira e universal. Diante disso, os estrangeiros que se preocupam em preservar e salvaguardar o espírito e a alma do lugar são artistas que foram sensíveis às práticas anteriores.

\section{METODOLOGIA}

O trabalho adota a perspectiva de variadas informações qualitativas (entrevistas) e quantitativas (inquérito). Segundo Dalfovo, Lana e Silveira (2008, p. 7), o método quantitativo caracteriza-se pelo emprego da quantificação, possuindo como "[...] diferencial a intenção de garantir a precisão dos trabalhos 
realizados, conduzindo a um resultado com poucas chances de distorções". Com o intuito de interpretar a realidade da olaria algarvia, utilizou-se também o método qualitativo:

[...] aquele capaz de incorporar a questão do significado e da intencionalidade como inerentes aos atos, às relações, e às estruturas sociais, sendo essas últimas tomadas tanto no seu advento quanto na sua transformação, como construções humanas significativas. (MINAYO, 1996, p. 10).

Os trabalhos de campo na região Algarve foram fundamentais para esse estudo quantitativo e qualitativo. A partir do contexto metodológico apresentado, este trabalho tem como ponto de partida de análise o "Modelo com os Elementos que Caracterizam as Olarias e os Oleiros do Algarve" (Figura 4), o que coloca o oleiro da terra e o artista estrangeiro no centro do debate e apresenta o município de Lagoa e sua olaria de Porches como escala de trabalho. Busca-se compreender a internacionalização e a modernidade dos lugares; além dos resultados do inquérito que ressalta os atuais sujeitos oleiros e suas relações com os espaços local, regional e global. 
Figura 4: Modelo com os elementos que caracterizam as olarias e os oleiros do Algarve

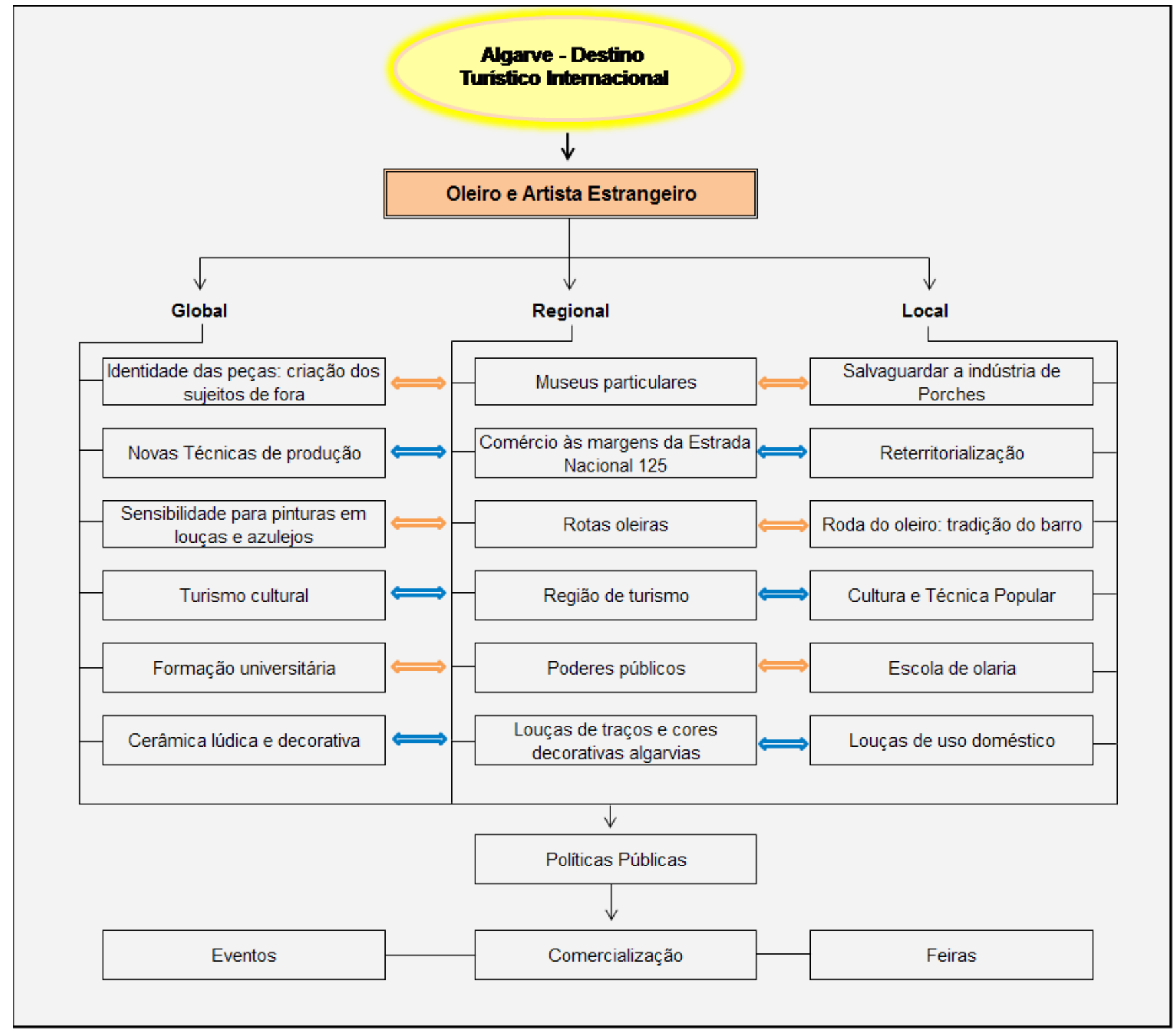

Fonte: Elaboração dos autores.

Há, pois, uma discussão que compartilha vários temas comuns e que possui temáticas tão abrangentes quanto divergentes não só nos campos da geografia, economia e turismo, como em áreas afins. Como dito, tal intervenção diz respeito à articulação dos oleiros algarvios com os artistas estrangeiros, em que a Figura 4 (modelo) se destaca como uma ferramenta de análise que marca essa ligação.

Essa reflexão, a partir do modelo apresentado, traz possibilidades multidisciplinares de discussões e análises fecundas, pois se coloca diante do cruzamento das relações socioculturais por meio do trabalho artesanal com o espaço. Este, de acordo com Santos, (2006, p. 21), não é "[...] apenas um 
ponto localizável em função de uma determinada ocorrência percebida como extraordinária, mas um lugar que nela teve a sua gênese".

Após uma pesquisa bibliográfica inicial, foi possível desenhar um questionário que permitisse a aproximação dos pesquisadores com a realidade encontrada no sul de Portugal, no que concerne a esta temática, o que foi estruturado conforme três blocos: o primeiro traz informações sobre a "Caracterização do Oleiro"; o segundo evidencia a "Caracterização das Relações Olaria - Políticas Públicas - Turismo"; e o terceiro (e último) bloco expõe a "Caracterização das Formas de Comercialização".

Em suma, o instrumento metodológico propõe nomeadamente um modelo de inquérito adaptado à realidade de Porches, na região Algarve, com o propósito de preencher algumas deficiências de conhecimento sobre o lugar. Na tentativa de interpretar essas lacunas:

O inquérito é uma ferramenta de investigação. No que toca ao inquérito, a escolha das variáveis a ter em conta para os estudos e medições em causa procurou dar resposta à necessidade de conhecer a população-alvo, estabelecer eventuais relações de causalidade e determinar as principais tendências, em termos de padrões espaciais. A informação acerca do grupo social que definimos foi processada de modo a tomar quantificáveis os resultados obtidos ou, pelo menos, nos casos em que pela sua própria natureza tal seja inviável, passíveis de interpretação e sistematização. (SANTOS, 2006, p. 41-42).

Os inquéritos foram realizados num universo de pesquisa de seis sujeitos, proprietários das olarias existentes em Porches, sendo que 66,4\% são do sexo masculino e 33,6\%, do feminino. Outra ordem importante e indispensável para a construção deste texto foi a pesquisa documental (levantamento das referências), recorrendo aos serviços das bibliotecas das Universidades do Algarve, de Coimbra e de Évora.

Essa etapa foi fundamental para a construção teórica. No entanto, constatouse uma relativa escassez de obras no que tange à olaria do Algarve e ao sul de Portugal, bem como ao turismo e ao patrimônio cultural regional. Para reduzir a lacuna teórica encontrada, foram fundamentais os trabalhos de campo e o levantamento de materiais em arquivos públicos municipais. 
Ao proporcionar uma melhor compreensão sobre as dinâmicas espaciais da escala de análise, o trabalho de campo foi uma oportunidade de se perceber que o espaço "[...] é codificado por categorias que permitem estruturá-lo: ele é ordenado em relação a um ponto de origem e às direções, o que permite situar os lugares uns em relação aos outros" (CLAVAL, 2006, p. 100). Desse modo, foi possível obter o material fotográfico, apresentando os lugares em recortes e quadrantes visuais.

Durante os trabalhos de campo ocorreram as entrevistas informais com alguns proprietários das olarias. É importante ressaltar que esta investigação se deu a partir da mescla do método quantitativo e qualitativo, tendo o trabalho oleiro como representante da arte popular portuguesa em um destino turístico internacional.

\section{O CONCELHO DE LAGOA E A FREGUESIA DE PORCHES: TERRA DE OLARIAS E OLEIROS}

Numa ótica geográfica e histórica, a atividade oleira sempre esteve ligada à região em que o concelho de Lagoa no Algarve se insere, especificamente entre a sede urbana do município e a freguesia de Porches. Nesse sentido, é possível considerar que tal discussão exercita uma dimensão científica abordando as vertentes cultural, patrimonial e de tradição, como apresentado na Figura 4. No caso específico deste artigo, a abordagem ficará enriquecida com a incorporação da temática "turismo" e sua relação com o artesanato popular oleiro, tornandose um tema central estimulante.

Recorda-se sinteticamente o que se entende pela história e geografia das olarias de Lagoa/Porches. Santos (2011, p. 472-473) lembra que a manufatura do barro nessa região é tão antiga quanto o seu passado, "[...] e essa mesma antiguidade acompanha-a desde o período neolítico, o que nos leva a considerar com alguma réstia de segurança ter sido a olaria a mais antiga se não a primeira indústria a florescer neste burgo milenário".

De acordo com Santos (2011, p. 473), a origem da cerâmica nessa região não é árabe, e sim de um passado mais remoto: "[...] no que se refere à olaria, outros 
povos mais antigo, nomeadamente os romanos, que tantas marcas nos deixaram da sua atividade neste domínio, poder-se-ão contar, também, como verdadeiros paladinos dessa indústria". De fato, os autóctones são influenciados pela arte de confecção de artigos de cerâmica produzidos pelos artífices dessa civilização, assim como de outros povos do Mediterrâneo Oriental que, ao desenvolverem todo o seu comércio ao redor do mar interior, se serviam das vasilhas de cerâmica para nelas acondicionarem e transportarem o vinho, o azeite e outros produtos.

Os autores Santos e Lourenço (2012) retratam em parte os contributos produzidos por Santos (2011), relatando que, efetivamente e com o decorrer dos tempos, a olaria de Lagoa foi uma atividade bastante próspera até meados do século $X X$, ao ponto de ter sido considerada a segunda maior indústria da região, atrás apenas de cortiça. Lagoa era, à época, um dos centros de olarias do Algarve, juntamente com Loulé, Olhão e Moncarapacho. Até os finais dos anos de 1960, "[...] a olaria de Lagoa manteve a importância que teve até então, fato que se deve à abundância, na região, da matéria prima - os famosos filões de barro vermelho" (SANTOS; LOURENÇO, 2012, p. 8).

Assim, preconiza-se essa abordagem histórica da olaria regional de Lagoa no Algarve como fator primordial para a compreensão da realidade contemporânea, realçando nesse contexto, e com maior relevância, a olaria da freguesia de Porches, com suas questões de identidade com o lugar, o papel dos sujeitos locais na manutenção de um ofício tradicional, bem como os reflexos dessa atividade artesanal no território e turismo. "Porches transporta consigo uma forte tradição na olaria, com um estilo e decoração próprios, antevendo-se, nas formas que usa, uma ligação direta com o passado distante, do qual ainda não se desligou" (SANTOS, 2011, p. 474).

Outro ponto a ser destacado nessa trajetória histórica diz respeito à criação de uma Escola-Oficina Municipal de Artesanato em Lagoa, em 1983. O curso de Olaria, enquadrado no âmbito do Fundo Social Europeu (FSE), é promovido pelo Centro Popular de Lagoa (Associação de Solidariedade Social), com o apoio da Câmara Municipal de Lagoa, no tocante às instalações e aos serviços, havendo nessa ação o "[...] intuito primordial de defender e continuar uma indústria tradicional, arte popular, que, a bem do patrimônio cultural da vila e país, deve 
merecer a firme atenção e carinho dos governantes locais e governamentais" (SANTOS, 2011, p. 473). Por circunstâncias de:

[...] um documento emanado da Câmara Municipal de Lagoa, temos conhecimentos que a olaria tradicional na vila de Lagoa foi recuperada por Fernando dos Santos Rodrigues, neto e filho de Mestres Oleiros da Vila, onde, como monitor dos cursos de olaria, subsidiados pelo Fundo Social Europeu e Estado Português, exerce a atividade na área da olaria cerâmica. (SANTOS, 2011, p. 473-474).

Como última nota nesse breve apontamento histórico, há o falecimento de Fernando Rodrigues dos Santos, no ano de 2013. Isso levou até o momento ao encerramento dos cursos e das atividades de olaria dessa escola, que era voltada essencialmente para o aspecto prático, em que o visitante ou turista podia observar ao vivo a confecção de objetos de cerâmica e olaria, com vistas a compreender as diversas fases por que passa a feitura de qualquer peça.

No que se refere ao trabalho da escola de olaria, pode-se afirmar que essa ação foi uma oportunidade de inclusão de sujeitos interessados na arte oleira, iguais e diferentes, e que se tornou possível por meio de atividades e atitudes que estimulavam "o respeito ao outro, a valorização das diferenças étnicoculturais, o resgate das relações entre território/poder" (VLACH, 2011, p. 18).

Essa forma de conhecimento é preciosa, pois, de alguma maneira, mantém a tradição, a cultura e a identidade regional, oportunizando aos aprendizes, aos visitantes/turistase aos demais sujeitoslocais avalorizaraquiloqueé pertencimento do lugar, registrando a arte de base local. Nessa perspectiva, a escola cumpria o objetivo de contribuir para a geração de processos do conhecimento, auxiliando na compreensão de processos culturais complexos, além de colaborar com a formação de sujeitos críticos e atuantes dentro de uma sociedade.

\section{INQUÉRITO COMO FERRAMENTA DE INVESTIGAÇÃO: CONHECENDO OS OLEIROS DE PORCHES}

Interessa aqui, sobretudo, dar uma ideia sobre quem são os sujeitos oleiros de Porches em Lagoa, apresentando o método quantitativo do trabalho, que tem, entre os objetivos, ilustrar o universo estudado. A primeira questão mostra 
o local de nascimento dos atuais oleiros do lugar na Figura 5, em que o maior número (50,2\%) é de origem algarvia (Lagoa e Armação Pêra) e outros 33,2\% são oriundos do estrangeiro (Escócia e Irlanda).

Na terceira questão, Figura 6, é caracterizada a classe etária, ressaltando que a maioria dos oleiros, 49\%, tem idade entre 50 e 65 anos. Os dados mostram um envelhecimentodessestrabalhadores, poisnãofoiencontradonenhumproprietário das olarias com idade entre 18 e 33 anos. Todos os entrevistados são casados e, no caso de Algarve, foi afastada a hipótese de baixa qualificação acadêmica/ escolar dos proprietários das olarias, pois $50 \%$ possuem o ensino secundário completo e outros $50 \%$, cursos superiores (licenciatura/bacharelado).

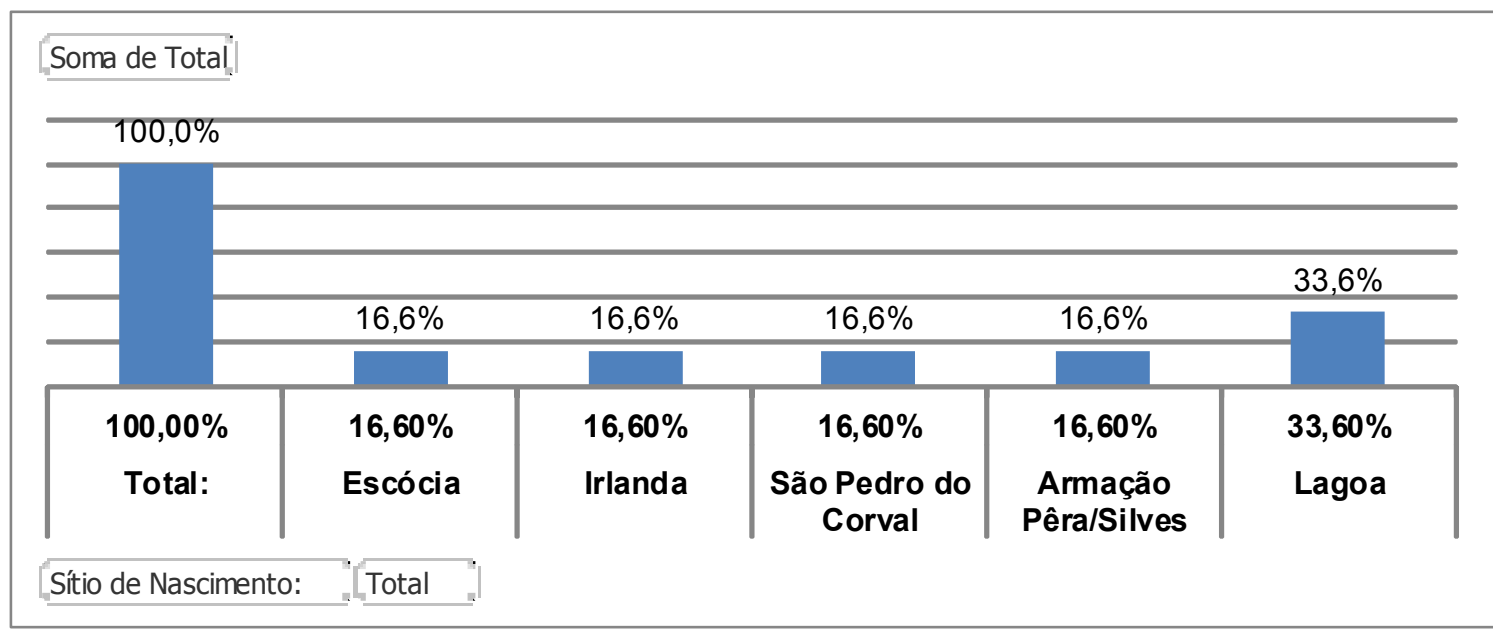

Figura 5: Local de nascimento dos oleiros do Algarve

Fonte: Elaboração dos autores.

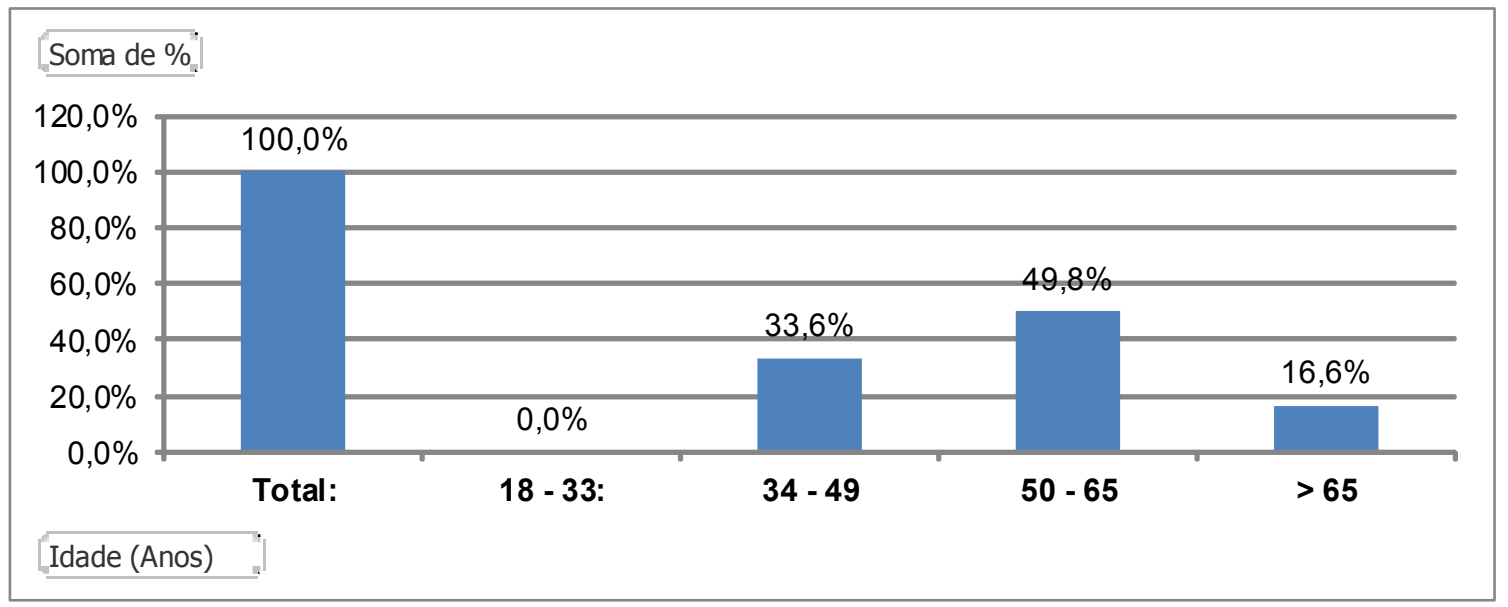

Figura 6: Faixa etária dos oleiros algarvios

Fonte: Elaboração dos autores. 
A fim de reforçar a formação profissional dos oleiros de Porches, buscou-se conhecer como ocorreu o processo de aprendizagem da profissão. O resultado dessa questão, conforme a Figura 7, mostra que apenas 16,6\% aprenderam o ofício com parentes, principalmente com o patriarca da família. Enquanto isso, $33,2 \%$ tornou-se artesão do barro pelas mãos de outros oleiros, e a maioria, $50 \%$, obteve suas formações em escolas.

É fundamental que a Câmara de Lagoa, em parceria com o Governo de Portugal, retome o projeto da Escola-Oficina Municipal de Artesanato que foi paralisado nos últimos anos, pois o ensino é uma prática social relevante no processo de formação e de manutenção da cultura popular regional. Dessa maneira, os interessados na arte oleira poderão experimentar um cotidiano repleto de possibilidades econômicas.

Na tentativa de interpretar os significados de existência desse ofício tradicional em Porches, nas primeiras décadas do século XXI, optou-se por saber quanto tempo os inquiridos trabalham com o artesanato oleiro. O maior grupo, 83,4\%, trabalha com esse ofício há mais de 30 anos; e 16,6\%, entre 26 e 30 anos. Os dados demonstram uma falta de interesse dos jovens em aprender a olaria e uma necessidade absoluta de renovação para que essa tradição algarvia não desapareça.

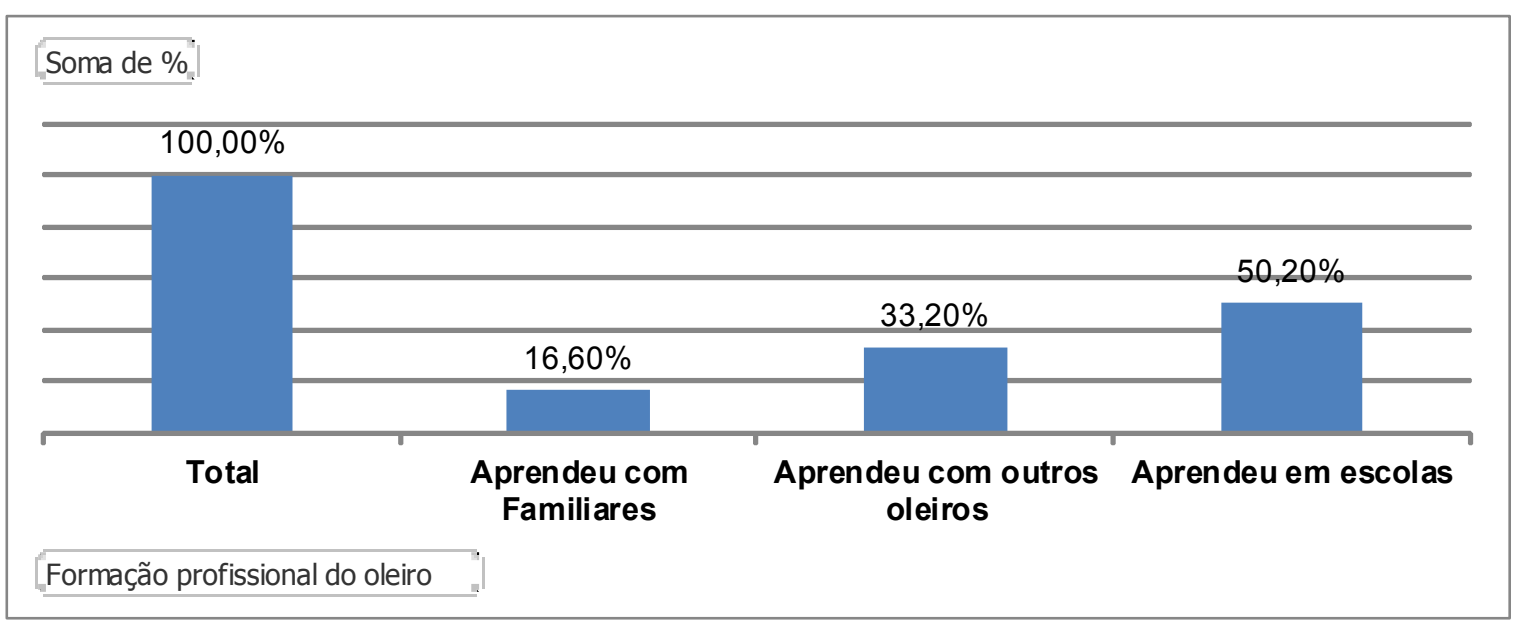

Figura 7: Formação profissional dos oleiros algarvios

Fonte: Elaboração dos autores.

Procurou-se verificar a quantidade de pessoas que trabalham em cada olaria de Porches (Figura 8), tendo em vista a necessidade de conseguir dados que 
demonstram o poder de geração de emprego e renda, uma vez que não foi encontrado nenhum trabalho de investigação que tenha abordado esse assunto. Em 16,6\% das olarias há um único trabalhador, que também é o proprietário do negócio. Com dois trabalhadores, normalmente esposa e esposo, teve-se o universo de $16,6 \%$, o que demonstra uma perspectiva de base familiar.

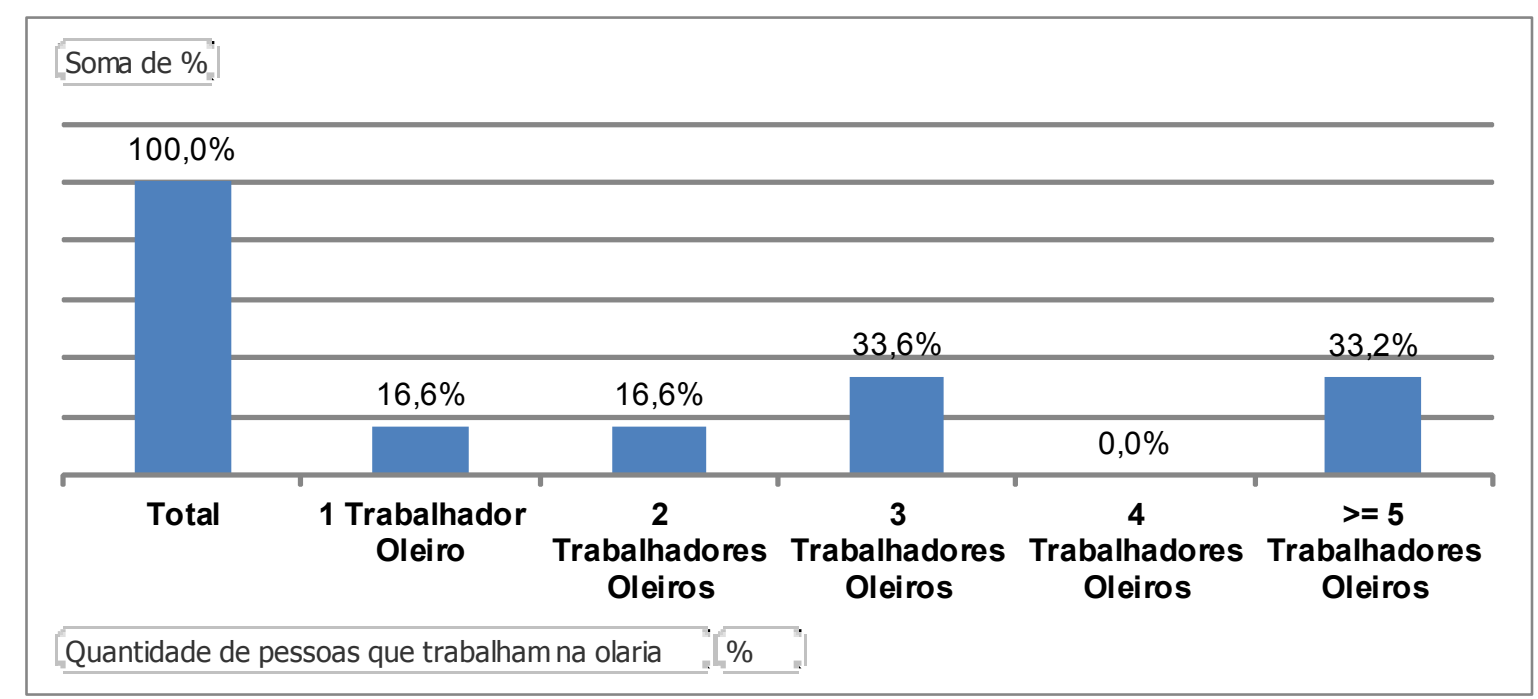

Figura 8: Número de trabalhadores nas olarias de Porches/Lagoa/Algarve Fonte: Elaboração dos autores.

Nesse horizonte, 33,6\% dos estabelecimentos oleiros possuem três pessoas que executam seu labor - vale reconhecer que esse universo também revela olarias que têm em sua base o trabalho familiar. Enquanto isso, 33,2\% das olarias empregam entre cinco e dez funcionários. Sem dúvidas, a pintura das cerâmicas é a principal tarefa executada pelos sujeitos nas empresas que mais oferecem empregos, sendo que há um maior número de empregos para o sexo feminino, com $65,3 \%$, e $34,7 \%$, para o grupo masculino.

No Algarve, a tendência atual é deixar para os grupos gestores familiares a responsabilidade de exploração da atividade e da manutenção da arte oleira popular tradicional em pequenas empresas. Entretanto, é fundamental que o setor público esteja presente e atue como parceiro nesses lugares, seja com maiores investimentos em promoção, divulgação, sensibilização da opinião pública, no apoio de formação da mão de obra, ou na assistência financeira em relação à infraestrutura, criando estratégias de desenvolvimento e valorização dessa arte popular. 
Já no que concerne à promoção ou à divulgação de cada olaria, as informações apontam que 33,6\% das empresas contam com o apoio da Câmara Municipal de Lagoa e Entidade Regional de Turismo. Convém salientar que os $66,4 \%$ que disseram não receber nenhum apoio fazem parte dos projetos de divulgação dos órgãos públicos, mas o que foi percebido durante os trabalhos de campo é que não existem diálogos entre os dois segmentos para traçar metas desejadas de divulgação.

Em termos gerais, 100\% dos inquiridos disseram vender seus produtos em comércio próprio. Desse universo, 83,4\% ainda expõem e comercializam seus artesanatos em feiras e eventos. Segundo eles, os produtos não são colocados nos postos de turismo da Entidade Regional de Turismo do Algarve em razão da falta de interesse do órgão público, mas foi percebida, nos diálogos de campo, a existência de insatisfação e de certa resistência dos inquiridos com relação aos gestores do turismo regional.

Assim, faz-se relevante retornar à discussão sobre quais meios de divulgação são utilizados: $33,6 \%$ não anunciam seus produtos por meio de nenhum meio de comunicação. Tal resultado não reflete a realidade, pois os oleiros são beneficiados pelos trabalhos desenvolvidos na Câmara Municipal de Lagoa e Entidade Regional de Turismo. Cumpre ressaltar que 66,4\% disseram que utilizam os meios de comunicação para anunciar suas mercadorias.

É preciso considerar que $100 \%$ (Figura 9) dos entrevistados, no que tange ao universo de $66,4 \%$ que divulgam seus produtos, disseram utilizar a internet (páginas de Facebook, e-mails, sites e blogs) como meio de divulgação e promoção - um aspecto em destaque é o uso da ferramenta Facebook, tornando-se a mais citada pelos proprietários das olarias. Em contrapartida, $50 \%$ apontaram o uso de cartazes, folhetos, revistas e museu itinerante, com vistas a colocar as peças em exposição. Outro fator relevante é que nenhum inquirido apresentou o uso das emissoras de televisão e rádio. 


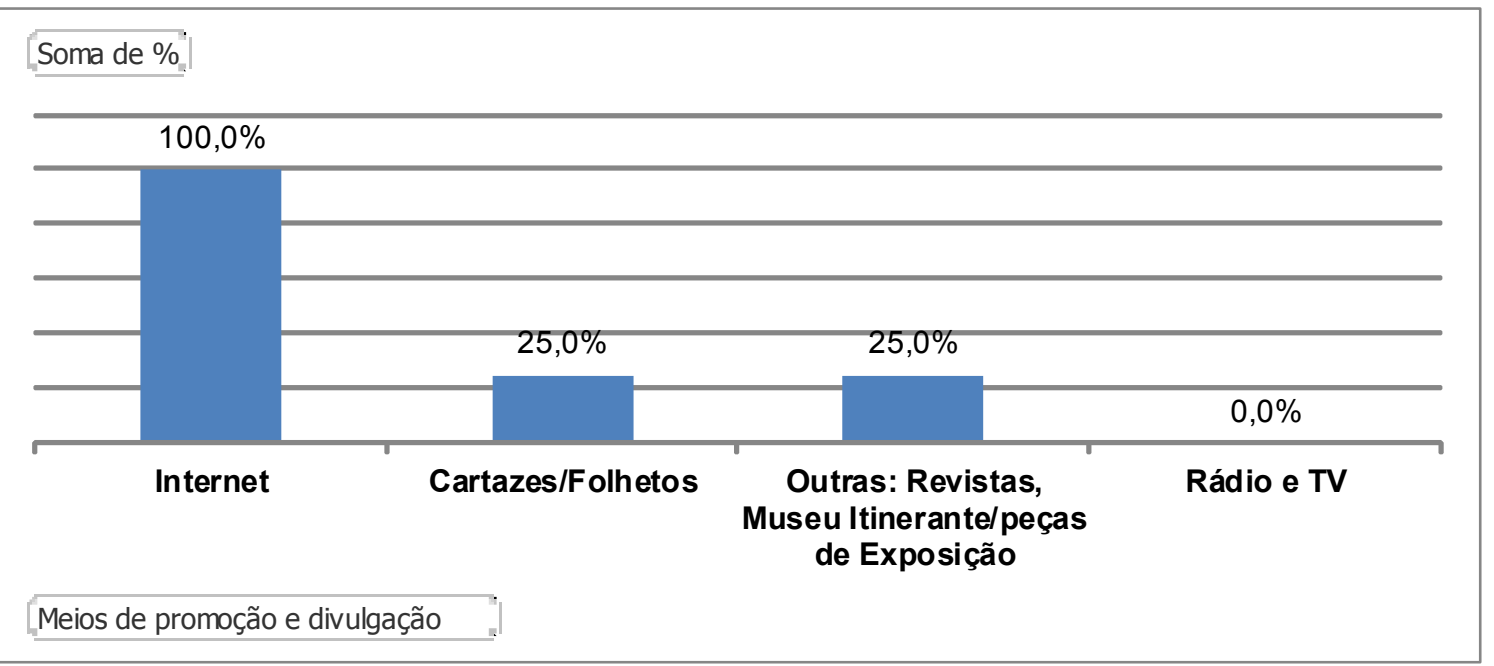

Figura 9: Formas de divulgação nas olarias do Algarve Fonte: Elaboração dos autores.

Durante a obtenção de dados no campo, foi solicitada aos sujeitos inquiridos uma avaliação sobre o incentivo da Entidade Regional do Turismo e da Câmara de Lagoa em relação às olarias do Algarve (Figura 10). É possível iniciar essa discussão apontando que apenas 16,6\% avaliaram como ótimo o trabalho desenvolvido pelos órgãos públicos, pois, segundo os entrevistados, os órgãos públicos são sempre ausentes, e isso sugere que o Estado também seja ausente. Houve ainda 50,2\% que não se dispuseram para opinar sobre o assunto, o que demonstra as dificuldades dos sujeitos em avaliar o contexto atual.

Os dados apresentados que abrangem o universo maior são preocupantes na avaliação desta pesquisa, pois deixam uma lacuna no processo de melhor avaliação do papel dos órgãos públicos situados na região Algarve, embora não se tenha aqui como propósito o esgotamento deste assunto.

Com o foco na investigação sobre as peças produzidas nessas olarias, buscou-se saber se elas se inserem na cultura, na identidade e na realidade local, destacando se tais mercadorias têm um caráter prático ou decorativo. Desse modo, $100 \%$ dos inquiridos afirmaram que as peças feitas nas olarias são de caráter prático e decorativo; no entanto, as decorativas são as mais comercializadas, o que viabiliza a existência dessa arte popular com o barro no contexto global, regional e local.

De forma geral, foram consideradas algumas questões básicas sobre a comercialização dos produtos: "Como é realizada?" "Quem são os principais 
clientes?". Nesse contexto, $100 \%$ disseram que a comercialização tem se constituído na própria região Algarve, para turistas e moradores, como mostra a Figura 11. Destes, 16,6\% ressaltam que a exportação ocorre por meio de uma empresa com sede em Lisboa, ao passo que 50,2\% disseram comercializar para o exterior por meio da internet. Isso reforça a presença dos turistas nas olarias e, ao mesmo tempo, salienta o seu poder de conhecimento, conforme a afirmação de uma empresária algarvia:

Os alemães e os ingleses já têm certa tradição a comprar e conhecem a peça de boa qualidade. Muitas vezes já têm coleção em casa. Conhecem o artesanato de boa qualidade. E nós temos cá clientes que já vão pra [sic] terceira geração a comprar cá peças. Esses sabem o que é genuíno [...] que é a maneira de pintar, sem usar estampados, tudo a mão e as pessoas conhecem. E quem faz coleção escolhe geralmente essas peças. Esses sabem que não há duas peças iguais. Fazem parecidos, mas não é igual. Cada uma tem a sua especificidade, o que diferencia uma das outras. (ENTREVISTA INFORMAL, ago. 2014).

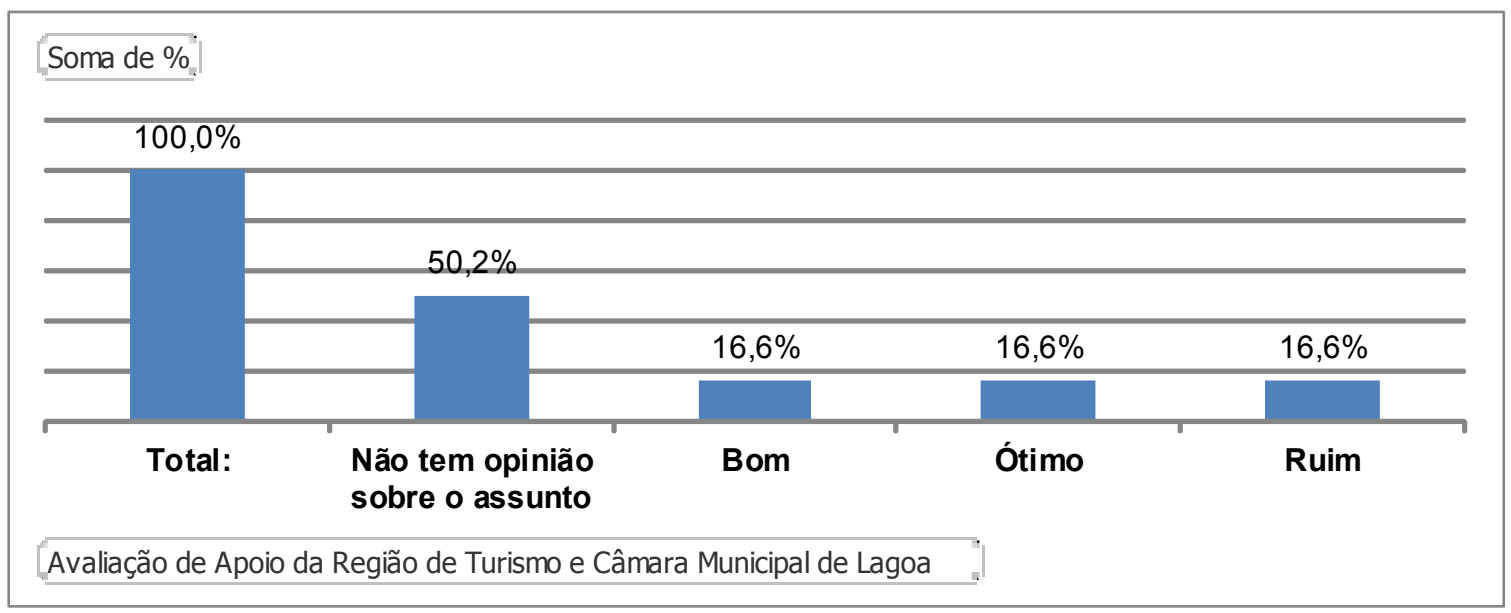

Figura 10: Apoio da Entidade Regional de Turismo e Câmara de Lagoa Fonte: Elaboração dos autores. 


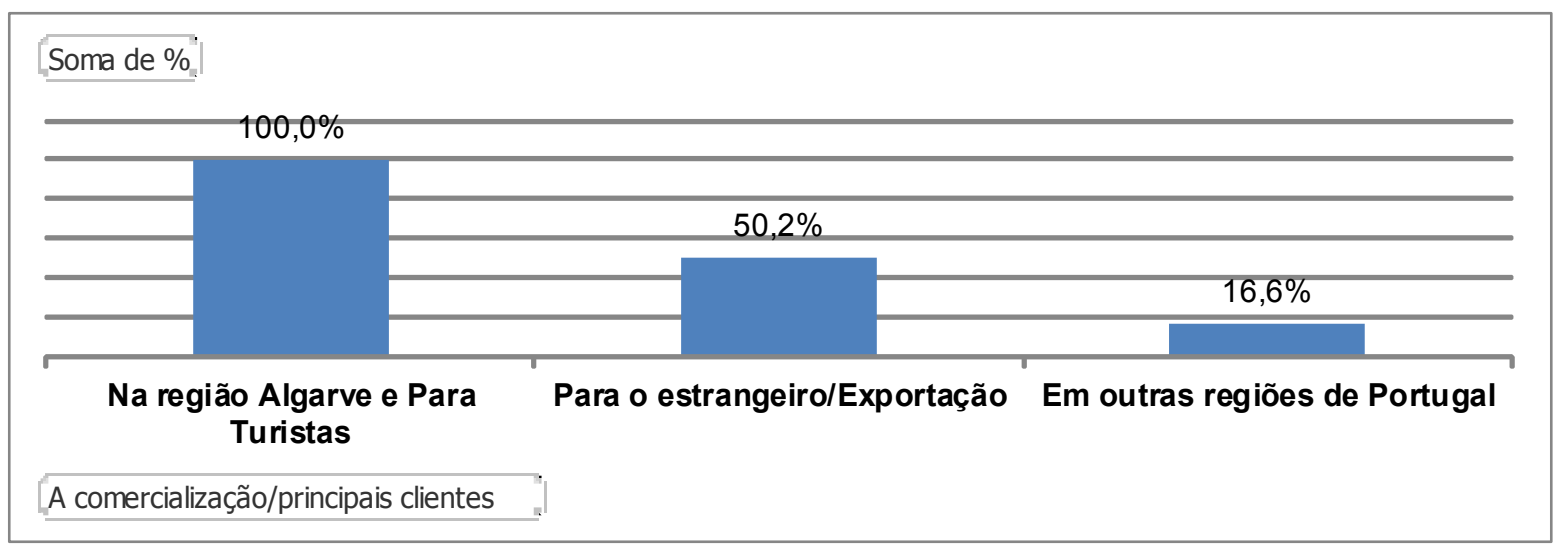

Figura 11: Comercialização dos produtos oleiros algarvios

Fonte: Elaboração dos autores.

Nesse contexto, tencionou-se conhecer os países consumidores dos produtos das olarias de Porches no Algarve: $83,4 \%$ dos inquiridos citaram os EUA e nações da União Europeia, como Inglaterra, Alemanha, França e Itália. Outros 16,6\% destacaram Brasil, México, Macau e países de língua portuguesa na África, especialmente Angola e Moçambique. Para finalizar o inquérito, é possível considerar que $100 \%$ dos sujeitos entrevistados não fazem parte de nenhuma associação de oleiros; tal fato mostra que os oleiros não se comunicam, o que é um forte entrave para a continuação e existência dessa tradição no Algarve. Sendo assim, é primordial que esses profissionais se organizem de fato, potencializando a tradição e o trabalho com o barro no contexto regional.

Com base nesses apontamentos, não se pode deixar de reconhecer que a existência de sujeitos ou atores sensibilizados com a arte popular oleira é fundamental para que essa atividade tradicional em Porches/Lagoa/Algarve tenha conseguido chegar às primeiras décadas do século XXI. Esses sujeitos sensibilizados se fazem presentes em contextos e lugares muito particulares, singulares e sob uma perspectiva única de viver o artesanato de barro. São, porquanto, pessoas sensíveis à confecção de objetos que outros deixaram marginalizados ao longo do tempo.

Esses comerciantes oleiros da região Algarve conseguem perceber, manter, sentir e entender o potencial de riquezas que está à sua volta. Eles são essenciais para que a tradicional olaria do Algarve consiga existir, sobreviver e atingir os patamares desejados e para que não desapareçam na sua totalidade. Tal 
processo, com o apoio de órgãos públicos, poderá despertar o interesse e o comprometimento de novos sujeitos locais, pois são deles as responsabilidades de manter uma tradição que identifica Porches e outras regiões do Algarve. Esse contexto de perspectiva e futuro permite dizer que:

Porches has proved that it is possible for hand-crafted articles to attract a sufficiently large public to survive on their own merit, and it is noteworthy that this venture was originally financed by the paintings. The colorful jugs and dishes are the most popular products with foreign and Portuguese visitors, but the work of the Pottery is now slowly expanding into decorative tiles, painted on commission for residents in Algarve. (WALMISLEY, 1983, p. 11).

O mundo, o espaço e as tradições regionais, como as olarias, mudam o tempo todo, não são estáticos; no entanto, se antigos ofícios populares permanecerem fixos diante dos fluxos, seus conteúdos, densidades e particularidades essenciais tendem a desaparecer. Reconhecer as mutações e se perceber no processo são aspectos fundamentais para as tradições se manterem diante daquilo que é novo, mesmo sofrendo adaptações.

Outro ponto pertinente é que o turista que chega ao Algarve é cada vez mais uma pessoa culta, interessada pelas artes e cultura. É um sujeito observador que está atento às tradições locais e que pretende encontrar sinais de identidade local; ele tem procurado, de fato, as diferenças, com o objetivo de ter uma experiência enriquecedora para o espírito e a alma. Com isso, há um sentido de deixar sua residência para ir a novos lugares, pois, se ficar tudo igual em todos os espaços e territórios, a experiência deixa de ser única e reveladora.

Não existe uma organização local e regional da olaria no Algarve, o que dificulta a permanência e a continuidade dessa tradição, mesmo os atores locais e regionais sabendo das forças culturais que determinam a vocação oleira no contexto regional e que asseguram uma identidade associada ao modo de vida e de trabalho com o barro. Em todos os casos investigados durante os trabalhos de campo, foi identificado nas realidades vivenciadas que tais populações não conversam entre si e percebem o outro apenas como um concorrente comercial, sem considerá-lo um parceiro no desenvolvimento de interesses comuns. 


\section{CONSIDERAÇÕES FINAIS}

Embora, atualmente, não deixe de ser um ofício ligado à atividade turística, a olaria do Algarve não pode ser vista apenas como um negócio comercial voltado para o turismo, visto que abrange um componente histórico, cultural e de tradição regional. Desse modo, as análises e as compreensões da olaria tradicional e do artista estrangeiro foram elementos de um panorama contemporâneo em que se evidenciam mudanças estruturais, culturais e sociais no Algarve, com ênfase no sentido da aparente perda de uma tradição popular, diante do enfraquecimento dos interesses pela arte oleira.

Dizer que as olarias de Porches/Lagoa/Algarve desaparecerão neste século XXI é um enorme risco. De fato, os tradicionais sujeitos oleiros (atualmente 40,2\%) demonstraram, ao longo do século passado, uma enorme capacidade de resiliência, isto é, são dotados de enorme capacidade adaptativa, mesmo necessitando receber influências e contribuições de artistas estrangeiros que, de forma direta, foram fundamentais para que a olaria popular continuasse a existir.

Os oleiros dessa região, associados aos artistas estrangeiros e totalizando $83,4 \%$, demonstraram que são capazes de se recuperar de situações adversas, como crises econômicas e grandes transformações industriais e tecnológicas. Em tempos de mudança, foram capazes de suportar as rupturas e de se recuperar poucas décadas depois, buscando difundir e promover sua arte em um cenário que se fortaleceu como destino internacional maduro, celebrando a sua olaria como algo internacional.

Em busca do direito de sobrevivência da arte oleira, os oleiros migraram suas olarias e comércios para as margens da Estrada Nacional 125 e se reterritorializaram num esforço de aproximação com os turistas que passaram a chegar ao Algarve a partir da década de 1960. É sabido que essa estratégia de mudança nas relações espaciais e econômicas oportunizou o sentido de existência e permanência da arte popular e de continuar sendo oleiro. Cumpre notar, ainda, que a presença do artista estrangeiro na região, 33,2\% dos inquiridos, contribuiu com a forte preocupação em manter e conservar uma atividade dos moradores nativos. 
A realidade analisada demonstra que a apropriação de novos territórios foi favorável para manter valores, práticas, costumes e culturas elaboradas por diferentes grupos de famílias nativas e estrangeiras envolvidas com o saber fazer oleiro, permanecendo nesse trabalho como marcas que identificam a região algarvia. Os depoimentos e os números aqui relatados testemunham diversas experiências de oleiros tradicionais e de artistas estrangeiros - estes atuaram como fundantes no surgimento de ideias criativas, entre elas a pintura e o ensino, revelando ações e significados que possibilitaram criar peças e outros espaços que passaram a compor o destino turístico internacional.

Diante do universo analisado, é possível caracterizar a olaria algarvia como um lugar de trabalho feminino, totalizando 65,3\% dos empregos. A gestão é de base familiar, que assume as estratégias de desenvolvimento e valorização dessa arte popular. No que concerne à promoção ou à divulgação, apenas 33,6\% admitem contar com o apoio da Câmara Municipal de Lagoa e Entidade Regional de Turismo do Algarve. Outro dado relevante é que os trabalhadores oleiros são, sobretudo, idosos, com média de idade entre 50 e 65 anos.

Em síntese, é indispensável que as autoridades algarvias saibam aproveitar a presença desses artistas estrangeiros com suas ideias criativas, promovendo parcerias com os setores privados principalmente. Qual é, afinal, a importância desse artista estrangeiro para a olaria do Algarve? Talvez seja o sujeito que buscou de forma mais incisiva a preservação e a defesa de uma cultura popular, dialogando e trocando experiências.

\section{REFERÊNCIAS}

CALADO, José. Redondo - terra de oleiros. Évora (Portugal): Gráfica Eborense, 2013.

CAMPOS, M. da G. de C. Causa geográfica do desenvolvimento das olarias na Baixada Guanabara. Revista Brasileira de Geografia, [s.I.], ano 17, n. 2, abr./jun. 1955.

CLAVAL, Paul. Abordagens da geografia cultural. In: CASTRO, Iná Elias de; GOMES, Paulo Cesar da Costa; CORRÊA, Roberto Lobato (Orgs.). Explorações geográficas: percursos no fim do século. Rio de Janeiro: Bertrand Brasil, 2006.

CONDE, Antónia F. Mãos que criam - a olaria em S. Pedro do Corval. Reguengos de Mosaraz 
(Portugal): Papel \& Tinta, 2013.

CUNHA, L. Perspectiva e tendências do turismo. Lisboa (Portugal): Edições Universitárias Lusófonas, 2003.

CUNHA, L. Economia e política do turismo. Lisboa (Portugal): Editorial Verbo, 2006.

CUNHA, Licínio. Turismo em Portugal: sucessos e insucessos. Lisboa (Portugal): Soares Artes Gráficas; Edições Universitárias Lusófonas, 2012.

DALFOVO, Michael Samir; LANA, Rogério Adilson; SILVEIRA, Amélia. Métodos quantitativos e qualitativos: um resgate teórico. Revista Interdisciplinar Científica Aplicada, Blumenau, v. 2, n. 4, p. 1-13, 2008.

FREIRE, Rita S. O ceramista escocês. Lagoa (Portugal): Arquivo Público de Lagoa, 2013.

FREITAS, Lima de. Porches e a recuperação do artesanato. GEA - Grupo de Estudos Algarvios, Algarve (Portugal), ano 1, n. 2, p. 3-7, 1978.

GONÇALVES, A. R. A componente cultural do turismo urbano com oferta complementar ao produto "Sol e Praia": o caso de Faro e Silves. Lisboa (Portugal): TdT, 2003.

INSTITUTO NACIONAL DE ESTATÍSTICA. Censos 2011. Disponível em: < http://www.censos. ine.pt>. Acesso em: 19 dez. 2014.

MINAYO, M. C. de S. O desafio do conhecimento: pesquisa qualitativa em saúde. 4. ed. São Paulo: Hucitec, 1996.

OLIVEIRA, Ataíde. Monografia de Porches. Faro (Portugal): Algarve em Foco, 1987.

PLA, J. La cerámica popular paraguaya. Assunção (Paraguai): Editora da Universidade Católica de Nuestra Señora de La Asunción, 2006.

RAVINES, R.; VILLIGER, F. La cerámica tradicional del Peru. Lima: Editorial Los Pinos, 1989.

RIBEIRO, Orlando. Portugal - o Mediterrâneo e o Atlântico. 4. ed. Lisboa (Portugal): Livraria Sá da Costa, 1986.

SANTOS, J. C. V. Região e destino turístico: sujeitos sensibilizados na geografia dos lugares. São Paulo: Allprint, 2013.

SANTOS, J. C. V. Políticas de regionalização e criação de destinos turísticos entre o Lago de São Simão e a Lagoa Santa no Baixo Paranaíba Goiano. Tese (Doutorado em Geografia) Universidade Federal de Uberlândia, Uberlândia, 2010. 
SANTOS, J. C. V.; SANTOS, R. J. Territórios do barrocal e as territorialidades dos oleiros no Baixo Vale Paranaíba goiano. In: ENCUENTRO DE GEÓGRAFOS DE AMÉRICA LATINA, 13. 2011, San José (Costa Rica). Anais... San José (Costa Rica): Universidad Nacional Costa Rica, 2011. v. único.

SANTOS, José Benvindo; LOURENÇO, Licínia. Olaria do concelho de Lagoa. Sintra (Portugal): Gényo Kriativo Artes Gráficas, 2012.

SANTOS, Maria da Graça Mouga Poças. Espiritualidade, turismo e território. Estoril (Portugal): Principia, 2006.

SANTOS, Rossel Monteiro. Histórico do Concelho de Lagoa. Lisboa (Portugal): Colibri Artes Gráficas, 2011. v. 2.

VLACH, Vânia Rubia Farias. Ensino de geografia, pesquisa, referenciais teórico-metodológicos: a atuação dos jovens no mundo atual. In: CAVALCANTI, L. de S.; BUENO, M. A.; SOUZA, V. C. de (Org.). A produção do conhecimento e a pesquisa sobre o ensino da geografia. Goiânia: Editora da PUC, 2011.

WALMISLEY, Sarah. The story of Porches' pottery. Lisboa (Portugal): Casa Portuguesa, 1983. 